Available online at GSC Online Press Directory

GSC Biological and Pharmaceutical Sciences

e-ISSN: 2581-3250, CODEN (USA): GBPSC2

Journal homepage: https://www.gsconlinepress.com/journals/gscbps

(RESEARCH ARTICLE)

\title{
Sumain nutritional supplement: Formulation, physico-chemical and nutritional assessment of its flour
}

\author{
Arogba Sunday S $1,{ }^{*}$, Akpala Suleiman N ${ }^{2}$, Amlabu Emmauel ${ }^{1}$ and Amodu Lazarus ${ }^{3}$ \\ ${ }^{1}$ Biochemistry Department, Kogi State University, PMB 1008, Anyigba, Nigeria. \\ 2 Microbiology Department, Kogi State University, PMB 1008, Anyigba, Nigeria. \\ ${ }^{3}$ Fenlab \& Company Nigeria Limited, No. 1 Abeokuta Street, Area 8, Garki, Abuja, Nigeria.
}

Publication history: Received on 11 March 2020; revised on 26March 2020; accepted on 28 March 2020

Article DOI: https://doi.org/10.30574/gscbps.2020.10.3.0061

\begin{abstract}
The paper reports in-part results of long-term study to investigate potential health benefits of SNS in improving diet quality to reverse severe catabolic stress in subjects with protein-energy malnutrition (PEM) and immune crisis. SNS was formulated as composite flour using yellow soyabean, red-skin groundnut, white sorghum, white and yellow maize seeds in ratio 4:2:3:2:2. Soaking and/or dehulling, toasting, and milling were initial major treatments given to each seedtype. The SNS sample was quantified for proximate composition, phytochemicals, anti-nutrients, minerals, vitamins, fatty acid and amino acid profiles using appropriate standard methodologies. SNS had dry 97\% matter content, 464 $\mathrm{kcal} / 100 \mathrm{~g}$ gross energy, $19 \%$ crude fat, $33 \%$ crude protein, and $2 \%$ ash. Prevalent phenolic compounds (gallic acid, quercitin, catechin, tannins) and alkaloids (saponin, phytate, glycyrrhizic acid) were low (5 - $18 \mathrm{mg} \%$ ) while oxalate was $76 \mathrm{mg} \%$; appreciable amounts of macro-elements ( $\mathrm{Na}, \mathrm{K}, \mathrm{Mg}$, P, and $\mathrm{Ca}$ ) as $6-17 \mathrm{mg} \%$, trace elements (Mn $159, \mathrm{Zn}$ 164, and Fe $260 \mu \mathrm{g} / \mathrm{g}$ ) and pro-vitamin A, vitamins B 6 , B12 and C. SNS contained high quality fatty acids (PUFA/SFA = 3.22 against expected $\geq 0.4$, and $\omega 6 / \omega 3=0.71$ against expected $\leq 4.0$ in conformance with FAO/WHO. Compared with soya bean and groundnut, four 'semi-essential' amino acids (glutamine, glycine, proline, alanine) and four essential amino acids (leucine, tryptophan, phenylalanine and isoleucine) were significantly higher $(\mathrm{p}<0.05)$; latter were higher than required by FAO/WHO $(\mathrm{p}<0.05)$. Conclusively, SNS was a potential food supplement. Report on in vivo studies was recommended to support the present proposition.
\end{abstract}

Keywords: Sumain Nutritional Supplement (SNS); Formulation; Proximate Composition; Physico-chemical analysis; Nutritional Assessment.

\section{Introduction}

The formulation of multigrain flour with high protein plant sources such as soybean, are among the efforts made to improve human diet. The dietary approach helps to complement the essential amino acid imbalance of tryptophan and lysine which are peculiarly low in cereal grains like maize and sorghum [1]. There are twenty known monomeric amino acids of proteins. Humans can synthesize eleven amino acids while the others are essential and must be acquired from diets [2].

Grains of the leguminous family are important sources of lipid and fatty acids, particularly the unsaturated fatty acids such as oleic acid, linoleic acid, and linolenic acid. Alpha linolenic and linoleic acids are examples of omega-3 and omega6 fatty acids which are essential in human and animal nutrition, and must be obtained from diet $[3,4]$. Unprocessed

\footnotetext{
${ }^{*}$ Corresponding author: Arogba Sunday
} 
grains provide substantial amounts of minerals, vitamins, fibre and phytochemicals like phenolic compounds, carotenoids and phytates. Food items of plant origin which contain relatively high concentrations of bioactive phytochemicals are good sources of neutraceuticals that ameliorate certain nutritional and immunological problems [5].

Furthermore, plant foods provide most mineral nutrients essential for human and animal nutrition. Minerals present in body fluids and tissues are necessary for regulating several physiological processes essential to life. They are not energy producing substances, but play important physiological roles in the body. They could be classified as macro-elements, required in amount greater than $100 \mathrm{mg} / \mathrm{dl}$ or trace-elements required in amounts less than $100 \mathrm{mg} / \mathrm{dl}$. The habitual pattern of food consumption in several developing countries is a major cause for poor intake of trace elements of nutritional significance. Among these elements, iron and zinc whose deficiency lower the body immunity to infections is of greatest public health concern [6].

Micro-nutrients are as valuable for normal metabolism in human, as macro-nutrients. Some vitamins, for instance, can scavenge reactive oxygen species and some are prosthetic groups of many enzymes. Consequently, their prolonged deficiencies result in several human diseases [7].

Based on the nutritional and health benefits of essential nutrients in various grains, the objectives of this study were to conduct proximate, phytochemical, anti-nutrient, micronutrient (vitamins and dietary minerals), fatty acid, and amino acid analyses of Sumain product (a composite flour of cereals, legumes, and nuts). The report on the in vitro study hereby presented is intended to complement data from the in vivo research which is on-going in our laboratory on the nutritional benefits of the Sumain supplement (SNS).

\section{Materials and methods}

\subsection{Sample collection and processing}

Commercially available dried yellow variety of Soybean (Glycine max), red skin variety of Groundnut (Arachis hypogaea), white variety of Guinea Corn (Sorghum bicolor), yellow and white varieties of Maize (Zea mays) seeds were procured separately from Anyigba market, Kogi State, Nigeria.

Processing steps to effectively remove most anti-nutritional factors, as described by International Institute of Tropical Agriculture (IITA) [8] were adopted: The seeds were cleaned and sorted for wholesomeness. They were further subjected, where necessary, to soaking, draining, and and air-drying e.g. Guinea Corn and Soya bean, before dehulling, toasting and grinding into powdery form called "Sumain Nutritional Supplement (SNS)". Details of the treatments given are shown in Table 1.

\subsection{Proximate analysis}

Moisture, crude fat, protein, fibre, and ash contents were determined using methods described by Pearson [9]. Carbohydrate was calculated as percentage difference of the components determined. Measurements were conducted in triplicate, and results expressed in percentage.

\subsection{Phytochemical analysis}

Total polyphenol, flavonoid, flavonol, and tannin contents of methanolic extracts of SNS sample were quantified using appropriate methodologies and reference reagents as standards as described by Nana et al. [10] were adapted. SNS sample was extracted with $95 \%$ methanol for the determinations. Measurements were conducted in triplicate, and results expressed in milligram percent.

\subsection{Anti-nutrient analysis}

Oxalate and Phytate contents were determined by employing the methods described by Danso et al. [11] and saponin, as described by Obadoni and Ochuko [12]. SNS sample was extracted with $95 \%$ methanol for the determinations. Measurements were conducted in triplicate, and results expressed in milligram percent. 
Table 1 Processing conditions for production of sumain nutritional supplement (SNS) flour mix

\begin{tabular}{|c|c|c|c|c|c|c|c|c|c|c|c|c|}
\hline $\begin{array}{l}\text { Sample } \\
\text { type }\end{array}$ & Shelling & $\begin{array}{l}\text { Cleaning } \\
\text { / Sorting }\end{array}$ & $\begin{array}{l}\text { Mild } \\
\text { sprinkling } \\
\text { of water }\end{array}$ & $\begin{array}{l}\text { Soaking } \\
\text { for } 30 \\
\text { min / } \\
\text { Draining }\end{array}$ & $\begin{array}{l}\text { Air - } \\
\text { drying } \\
\text { at } \\
\text { ambient } \\
\text { temp. }\end{array}$ & $\begin{array}{l}\text { Dehulling } \\
\text { by milling / } \\
\text { Winnowing }\end{array}$ & Toasting & $\begin{array}{l}\text { Manual } \\
\text { dehulling }\end{array}$ & $\begin{array}{l}60 g \text { eqv. } \\
\text { Toasting } \\
\text { time } \\
(\mathrm{min})\end{array}$ & $\begin{array}{l}\text { Milling } \\
\text { into } \\
\text { flour }\end{array}$ & $\begin{array}{l}\text { Ratio } \\
\text { in } \\
\text { SNS } \\
\text { mix }\end{array}$ & $\begin{array}{l}\text { Weight (g) } \\
\text { in Batch } \\
\text { Production }\end{array}$ \\
\hline Groundnut & $\mathrm{y}$ & $\mathrm{Y}$ & & & & & $\mathrm{y}$ & $\mathrm{Y}$ & 1 & $\mathrm{y}$ & 1 & 300 \\
\hline Guinea corn & & Y & $\mathrm{y}$ & $\mathrm{y}$ & $\mathrm{y}$ & & $\mathrm{y}$ & & 2 & $\mathrm{y}$ & 1.5 & 450 \\
\hline $\begin{array}{l}\text { White } \\
\text { maize }\end{array}$ & & Y & $\mathrm{y}$ & & & Y & $\mathrm{y}$ & & 0.5 & $\mathrm{y}$ & 1 & 300 \\
\hline $\begin{array}{l}\text { Yellow } \\
\text { maize }\end{array}$ & & $\mathrm{Y}$ & $\mathrm{y}$ & & & Y & $\mathrm{y}$ & & 0.5 & $\mathrm{y}$ & 1 & 300 \\
\hline Soya bean & & $\mathrm{Y}$ & & $\mathrm{y}$ & $\mathrm{y}$ & Y & $\mathrm{y}$ & & 1.5 & $\mathrm{y}$ & 2 & 600 \\
\hline Total & & & & & & & & & & & & $1.95 \mathrm{~kg}$ \\
\hline
\end{tabular}

$\mathrm{y}=$ Treatment given 


\subsection{Mineral analysis}

Mineral content was analysed according to the method of AOAC [13] using an Atomic Absorption Spectrophotometer. Measurements were conducted in triplicate, and results expressed in milligram per gram sample for the macroelements, and microgram per gram fro trace elements.

\subsection{Vitamin content}

Vitamins were determined according to the methods of AOAC [14]. Measurements were conducted in triplicate, and results expressed in milligram per $100 \mathrm{~g}$ sample.

\subsection{Fatty acids}

Fatty acid composition of the SNS sample was analyzed using Agilent Gas Chromatograph (Model 6850A HP, Agilent Tech. Int'l, California, U.S.A.) as described by Ogunsina et al. [15]. Measurements were conducted in triplicate, and relative concentrations were expressed as equivalents of percentage Area under the graph.

\subsection{Amino acids}

The amino acid content this sample was determined according to official analytical method of American Association of Cereal Chemists [16], using LKB Biochrom 4150 (Alpha) Automatic Amino acid Analyzer. Measurements were conducted in triplicate, and results expressed in gram per $100 \mathrm{~g}$ protein of sample.

\subsection{Statistical analysis}

Standard Error of Mean (SEM) for triplicate measurements was calculated using the software at miniwebtool.com, while Means were separated by the Least Significant Difference Test at 95\% Confidence level. Values with different alphabets denoted significant difference at $\mathrm{p}<0.05$, as appropriate

\section{Results}

Table 2 Proximate composition of SNS Sample

\begin{tabular}{lc}
\hline Constituents & Conc. $(\mathbf{\%} \mathbf{~ w} / \mathbf{w})$ \\
\hline \multirow{2}{*}{ Moisture } & $3.3+0.04$ \\
Fat & $18.6+0.10$ \\
Protein & $33.0+0.23$ \\
Fibre & $0.7+0.01$ \\
Ash & $1.9+0.00$ \\
Carbohydrate (by difference) & $42.5+0.20$ \\
Energy $(\mathrm{kcal} / \mathrm{g})^{*}$ & $4.64+0.02$ \\
\hline \multicolumn{2}{r}{${ }^{*}$ where Energy (kcal/g) $=4(\mathrm{~g}$ protein $+\mathrm{g}$ carbohydrate $)+9(\mathrm{~g}$ Fat $)$} \\
$\quad$ Values are expressed as Mean \pm SEM of triplicates.
\end{tabular}

The SNS sample was dried to very low moisture content. It possessed high carbohydrate, protein, and fat contents. Protein:Fat was 2:1. However, ash and fibre contents were low. 
Table 3 Phytochemical and Anti-nutrient contents of SNS Sample

\begin{tabular}{lc}
\hline Constituents & Conc. (mg \%) \\
\hline Total Phenolics & $54.50+1.18$ \\
(Gallic acid) & $6.22+0.27$ \\
Total Flavonoids & $68.40+0.89$ \\
(Quercetin) & $8.90+1.76$ \\
(Catechin) & $9.32+1.21$ \\
(Caffeine) & $5.35+0.05$ \\
(Tannin) & $5.02+0.48$ \\
Total Glycosides & $45.50+1.07$ \\
(Glycyrrhizic acid) & $18.42+0.36$ \\
Total Alkaloids & $103.10+0.87$ \\
(Oxalate) & $73.40+0.70$ \\
(Saponin) & $13.13+0.30$ \\
(Phytate) & $17.12+0.26$ \\
\hline
\end{tabular}

Gallic acid constituted only $11 \%$ of total phenolics, while quercetin, catechin, caffeine, and tannin were $13,14,8$, and $7 \%$ of total flavonoids respectively. Appreciable quantity of glycyrrhizic acid (40\%) was detected among glycosides present. In similar vein, saponin was $12 \%$ but combined oxalate/phytate constituted $88 \%$ of total alkaloids.

Table 4 Mineral content of SNS sample

\begin{tabular}{|c|c|}
\hline Mineral Type & Conc. \\
\hline Macro-elements & $(m g / g)$ \\
\hline $\mathrm{Ca}$ & $17.1 \pm 0.02$ \\
\hline $\mathrm{Mg}$ & $7.9 \pm 0.03$ \\
\hline $\mathrm{K}$ & $5.9 \pm 0.01$ \\
\hline $\mathrm{P}$ & $10.1 \pm 0.01$ \\
\hline $\mathrm{Na}$ & $5.6 \pm 0.02$ \\
\hline Trace-elements & $(\mu g / g)$ \\
\hline $\mathrm{Mn}$ & $159.19 \pm 0.25$ \\
\hline $\mathrm{Fe}$ & $259.88 \pm 0.22$ \\
\hline $\mathrm{Zn}$ & $163.69 \pm 0.17$ \\
\hline $\mathrm{Cu}$ & $13.02 \pm 0.04$ \\
\hline $\mathrm{Sn}$ & $0.015 \pm 0.00$ \\
\hline $\mathrm{Pb}$ & $0.007 \pm 0.00$ \\
\hline $\mathrm{Cd}$ & $0.003 \pm 0.00$ \\
\hline $\mathrm{Se}$ & $0.006 \pm 0.00$ \\
\hline $\mathrm{Cr}$ & $0.538 \pm 0.01$ \\
\hline
\end{tabular}

Values are expressed as Mean \pm SEM of triplicates. 
The most abundant macro-element was calcium, followed by phosphorus, and magnesium. The least were sodium and potassium in equivalent concentrations. Similarly, manganese, zinc, and iron, in increasing order between 159 and 260 $\mu g / g$, were the abundant trace-elements in SNS sample.

Table 5 Vitamin Content of SNS sample

\begin{tabular}{lc}
\hline Vitamins & Conc.(mg/100g) \\
\hline A (retinol eqv.) & $3.77+0.06$ \\
B1 (thiamine) & $1.49+0.04$ \\
B2 (riboflavin) & $4.79+0.01$ \\
B3 (niacin) & $0.39+0.01$ \\
B6 (pyridoxine eqv.) & $7.16+0.02$ \\
B12 (cobalamin eqv,) & $2.13+0.01$ \\
C (L-ascorbic acid) & $6.76+0.02$ \\
E (tocopherol eqv) & $0.05+0.00$ \\
\hline & Values are expressed as Mean \pm SEM of triplicates.
\end{tabular}

SNS sample was a rich source of vitamins $B_{6}$ and $C_{2} B_{2}$ was next in abundance and was more than twice the concentrations of $\mathrm{B}_{1}$ and $\mathrm{B}_{12}$. Only trace amount of vitamin $\mathrm{E}$ was detected.

Table 6 Fatty acid profile of SNS sample compared with related ingredients

\begin{tabular}{|c|c|c|c|c|}
\hline \multicolumn{2}{|l|}{ Fatty acid (\%) } & \multirow{2}{*}{$\begin{array}{l}\begin{array}{l}\text { Conc. } \\
\text { Area \%) of SNS }\end{array} \\
\text { N/A }\end{array}$} & \multirow{2}{*}{$\begin{array}{l}\begin{array}{l}\text { Groundnut } \\
\text { kernel }^{*}\end{array} \\
8.8 \pm 0.5 \mathrm{~b}\end{array}$} & \multirow{2}{*}{$\begin{array}{c}\text { Soya bean }^{* *} \\
3.3 \pm 0.12 \mathrm{a}\end{array}$} \\
\hline Palmitic acid & C16:0 & & & \\
\hline Palmitoleic acid & $\mathrm{C} 16: 1 \omega 7$ & $1.8 \pm 0.02$ & $\mathrm{~N} / \mathrm{A}$ & $\mathrm{N} / \mathrm{A}$ \\
\hline Stearic acid & C18:0 & $11.7 \pm 0.02 b$ & $2.2 \pm 0.1 \mathrm{a}$ & $2.3 \pm 0.23 a$ \\
\hline Oleic acid & $\mathrm{C} 18: 1 \omega 9$ & $58.8 \pm 0.56 \mathrm{~b}$ & $22.6 \pm 1.6 a$ & $20.5 \pm 0.51 \mathrm{a}$ \\
\hline Linoleic acid & $\mathrm{C} 18: 2 \omega 6$ & $3.9 \pm 0.23 a$ & $40.5 \pm 1.1 b$ & $68.0 \pm 0.06 c$ \\
\hline Linolenic acid & $\mathrm{C} 18: 3 \omega 3$ & $16.2 \pm 0.02 \mathrm{~b}$ & $1.6 \pm 0.1 \mathrm{a}$ & $5.2 \pm 0.13 a$ \\
\hline \multirow[t]{2}{*}{ Arachidic acid } & $\mathrm{C} 20: 0$ & $\mathrm{~N} / \mathrm{A}$ & $1.7 \pm 0.3 b$ & $0.7 \pm 0.40 \mathrm{a}$ \\
\hline & $\mathrm{C} 20: 1$ & $\mathrm{~N} / \mathrm{A}$ & $2.5 \pm 0.6$ & $\mathrm{~N} / \mathrm{A}$ \\
\hline Arachidonic acid & $\mathrm{C} 20: 4 \omega 6$ & $7.6 \pm 0.24$ & $\mathrm{~N} / \mathrm{A}$ & $\mathrm{N} / \mathrm{A}$ \\
\hline \multicolumn{2}{|c|}{ Saturated fatty acid, SFA } & $11.7 \mathrm{~b}$ & $(12.7) \mathrm{b}$ & $6.33 a$ \\
\hline \multicolumn{2}{|c|}{ Monounsaturated fatty acid, MUFA } & $60.6 \mathrm{~b}$ & $25.1 \mathrm{a}$ & $20.47 a$ \\
\hline \multicolumn{2}{|c|}{ Polyunsaturated fatty acid, PUFA } & $37.7 \mathrm{a}$ & $42.1 \mathrm{a}$ & $73.20 \mathrm{~b}$ \\
\hline \multicolumn{2}{|l|}{ MUFA / SFA } & $5.18 \mathrm{c}$ & (1.98)a & $3.23 \mathrm{~b}$ \\
\hline \multicolumn{2}{|l|}{ PUFA / SFA } & $3.22 \mathrm{a}$ & (3.31)a & $11.56 \mathrm{~b}$ \\
\hline \multicolumn{2}{|l|}{$\omega 6 / \omega 3$} & $0.71 \mathrm{a}$ & $25.30 \mathrm{c}$ & $13.13 b$ \\
\hline
\end{tabular}


Low molecular weight fatty acids were absent in the SNS sample. Stearic acid was the only detectable saturated fatty acid, and oleic acid was the most prevalent among the unsaturated fatty acids. PUFA content was thrice that of SFA, and $\omega 3$-fatty acids were higher than $\omega 6$-fatty acids in concentration by $30 \%$.

Table 7 Mean concentration of amino acids in SNS sample compared with References

\begin{tabular}{|c|c|c|c|}
\hline $\begin{array}{r}\text { Amino acid (FAO/WHO, } \\
\text { g/100g protein)* }\end{array}$ & $\begin{array}{l}\text { Conc. }(\mathrm{g} / 100 \mathrm{~g} \\
\text { protein SNS) }\end{array}$ & $\begin{array}{l}\text { Conc. }(\mathrm{g} / 100 \mathrm{~g} \\
\text { protein soyabean)* }\end{array}$ & $\begin{array}{l}\text { Conc. }(\mathrm{g} / 100 \mathrm{~g} \\
\text { protein groundnut)* }\end{array}$ \\
\hline \multicolumn{4}{|l|}{ Essential amino acids: } \\
\hline Tryptophan (1.1)a & $12.43 \mathrm{~b}$ & $1.3 \mathrm{a}$ & $1.0 \mathrm{a}$ \\
\hline Leucine (6.6)a & $14.08 \mathrm{~b}$ & $7.8 \mathrm{a}$ & $6.4 \mathrm{a}$ \\
\hline Isoleucine (2.8) a & $3.29 \mathrm{bc}$ & $4.5 \mathrm{c}$ & $3.4 \mathrm{c}$ \\
\hline Phenylalanine (-) & $7.04 \mathrm{~b}$ & $4.9 \mathrm{a}$ & $5.0 \mathrm{a}$ \\
\hline Lysine (5.8) b & $3.54 \mathrm{a}$ & $6.4 \mathrm{~b}$ & $3.5 \mathrm{a}$ \\
\hline Histidine (1.9) b & $1.45 \mathrm{a}$ & $2.5 \mathrm{c}$ & $2.4 \mathrm{c}$ \\
\hline Threonine (3.4) b & $2.80 \mathrm{a}$ & $3.9 c$ & $2.6 \mathrm{a}$ \\
\hline Valine (3.5) b & $1.63 \mathrm{a}$ & $4.8 \mathrm{c}$ & $4.2 \mathrm{bc}$ \\
\hline Methionine (-) & $0.39 \mathrm{a}$ & $1.3 \mathrm{~b}$ & $1 . .2 \mathrm{~b}$ \\
\hline \% Proportion & 46.63 & & \\
\hline \multicolumn{4}{|l|}{ Non-essential amino acids } \\
\hline Glutamic acid & 2.72 & $\mathrm{~N} / \mathrm{A}$ & $\mathrm{N} / \mathrm{A}$ \\
\hline Glutamines & $19.43 \mathrm{a}$ & $18.7 \mathrm{a}$ & $18.3 \mathrm{a}$ \\
\hline Aspartic acid & 1.49 & $\mathrm{~N} / \mathrm{A}$ & $\mathrm{N} / \mathrm{A}$ \\
\hline Asparagine & $0.21 \mathrm{a}$ & $11.7 \mathrm{~b}$ & $11.4 \mathrm{~b}$ \\
\hline Alanine & $4.32 \mathrm{~b}$ & $4.3 \mathrm{~b}$ & $3.9 \mathrm{a}$ \\
\hline Proline $^{s}$ & $7.43 \mathrm{c}$ & $5.5 \mathrm{~b}$ & $4.4 \mathrm{a}$ \\
\hline Glycines $^{s}$ & $11.08 \mathrm{~b}$ & $4.2 \mathrm{a}$ & $5.6 \mathrm{a}$ \\
\hline Serine & $2.19 \mathrm{a}$ & $5.1 \mathrm{~b}$ & $4.8 \mathrm{~b}$ \\
\hline Tyrosines $^{s}$ & $1.49 \mathrm{a}$ & $3.1 \mathrm{~b}$ & $3.9 \mathrm{c}$ \\
\hline Cysteines $^{s}$ & $2.19 \mathrm{~b}$ & $1.3 \mathrm{a}$ & $1.3 \mathrm{a}$ \\
\hline Arginines & $0.96 \mathrm{a}$ & $7.2 \mathrm{~b}$ & $11.2 \mathrm{c}$ \\
\hline \% Proportion & $\mathbf{5 3 . 4 7}$ & & \\
\hline Ratio (Essential : Non-essential) & 0.87 & & \\
\hline
\end{tabular}

*Anon. [19], N/A=Not Available, Superscript ${ }^{s}=$ semi-essential or conditional amino acid.

Values are expressed as Mean of triplicate measurements. Values with same alphabets in a row are not significantly different at $\mathrm{p}>0.05$

Three most abundant amino acids in SNS sample were glutamine, leucine, and tryptophan, and in decreasing order. Methionine was the limiting amino acid. SNS exhibited 13\% shortfall in the ratio of essential amino acids to nonessential amino acids. 


\section{Discussion}

\subsection{Proximate composition analysis}

The proximate composition of SNS recorded in Table 2 indicated high dry matter content of 97\%, suggestive of longer shelf-life that would not easily promote mold growth.

The carbohydrate content of $42 \%$ was high enough to boost daily energy need of man. Based on available data on the protein and lipid contents of maize and guinea corn [20,21], those of soya bean and groundnut in SNS formulation had significantly improved the protein and lipid contents of the maize fraction by $267 \%$ and $365 \%$ respectively; and in similar vein, $206 \%$ and $272 \%$ for guinea corn fraction. Therefore, rather than living on a regimen of restricted diets of maize, or guinea corn alone, the composite flour of SNS would meet energy needs to overcome nutrient deficiency resulting from protein-energy malnutrition. For instance, the recommended daily allowance for protein is $0.8 \mathrm{~g}$ protein/kg body weight/day for adults, irrespective of age, gender, and body composition [22].

The very low fibre content of SNS was ascribed to the dehulling process employed on all the items in the formulation. It implied that the carbohydrate component of SNS would be easily digestible, and could be enhanced by the ash content which was about thrice higher than the fibre value. Ash content of seeds and tubers in the range of $1.5-3.5 \%$ had been recommended for both animal feeds, and human consumption $[23,25]$, which SNS ash value falls within. Furthermore, the metabolizable energy of SNS (4.64 kcal/g) was comparable with that of Afang (Gnetum Africanum) seeds (4.49 $\mathrm{kcal} / \mathrm{g}$ ). While SNS was a processed and edible product with low anti-nutrient content discussed below, Ekop [22] had advocated that raw Afang (Gnetum Africanum) seeds must be processed before consumption to reduce its high content of toxicants (tannin, oxalate, and phytic acid).

\subsection{Phytochemical and anti-nutritional contents}

Phenolic compounds of plant origin are commonly found in food, and constitute a wide array of biologically active substances. In addition, phenolic substances are good anti-aging, anti-carcinogenic agents, and offer cardiovascular protection [26]. Phenolics and flavonoids possess antioxidant activity and, hence, considered to have positive effects on human health and nutrition to reduce stress resulting from accumulation of reactive oxygen species [27]. Furthermore, antioxidant performance of any sample is better correlated by assessment of both phenolic-like compounds [28]. Phytochemical content of SNS sample (Table 3) showed equivalent concentrations of total flavonoids and phenolics, but gallic acid, quercitin, catechin, and caffeine present were of relatively low concentrations (6-8 $\mathrm{mg} \%$ ) and would probably not serve as good preservatives of SNS on prolonged storage.

As mentioned earlier, the SNS sample is safer for human consumption than raw Afang (Gnetum africanum) seeds which contain high toxic levels of oxalates (209.0 mg\%) and phytic acid (238.3 $\mathrm{mg} \%)$ [25]. Moreover, soya bean which is a constituent of SNS was processed in this study to relatively low level of $76 \mathrm{mg} \%$ oxalate. Up to $235 \mathrm{mg} \%$ was recorded in some cultivars of soya bean seeds, and $2-8 \%$ is absorbed by the body while the rest is excreted by the kidney [29]. The soaking and dehulling steps in the processing of the soya bean seeds in this study significantly reduced the oxalate content by $64 \%$ and, the phytate by $93 \%$. These values also represented their respective solubility factor in aqueous medium, where about $32 \%$ was insoluble possibly as calcium oxalate ( $\mathrm{CaOx}$ ), while phytic acid ( $\mathrm{InsP}_{6}$ ), which is the phosphorylated form of inositol, was very soluble possibly in sodium or potassium form. Phytate has beneficial benefit on health by reducing renal calcification caused by insoluble oxalate, and as claimed to have potential antioxidant activity [29].

Soya bean seed is known to contain four types of saponins (A, B, E, and DDMP) and the total concentration is more variety-dependent than cultivar-, or harvest age-dependent. The raw yellow variety contains $1.3 \mathrm{~g} \%$ and the black variety, $1.1 \mathrm{~g} \%$ [30]. The result was obtained as soya saponin Ba equivalent using a colorimetric method. It implied that the processing technique employed eliminated virtually all saponins in the formulation of SNS, with residual concentration of $1 \%$ soyasaponin equivalent. The result re-affirms the relatively safe consumption of SNS in diets.

Glycyrrhizic acid (glycyrrhizin) detected at $18 \mathrm{mg} \%$ level in SNS is a triterpenoid saponin glycoside in calcium or sodium form. The ammonium salt of glycyrrhizin is a flavour- enhancer, or sweetener known to be 50- to 100 -fold sweeter than sucrose [31]. It is hydrolysable by human intestinal flora to glycyrrhetinic acid, flavonoids, hydroxyl coumarins, and 
sitosterol which are absorbed and metabolized by the liver. These products participate in treatments of bronchitis, gastritis, and jaundice, due to their anti-inflammatory and antioxidant properties [32, 33].

\subsection{Mineral content}

The mineral content of SNS (Table 4) was found to contain a considerable amount of calcium (Ca), phosphorus (P) and Magnesium (Mg), in decreasing concentrations of $\mathrm{mg} \%$. The least macro-elements were sodium and potassium which were in equivalent concentration. These elements are required for the development of bones, teeth, proper nerve functioning, maintenance of acid-base balance and nerve transmission.

Among the trace-elements examined, appreciable amount of $\mathrm{Fe}, \mathrm{Zn}$, and $\mathrm{Mn}$ in decreasing range of $260-160(\mu \mathrm{g} / \mathrm{g})$, and a concentration ten-fold less of $\mathrm{Cu}$ were recorded. $\mathrm{Fe}$ is a constituent of hemoglobin that transports oxygen in the body, and serves as a co-factor involved in biological oxidations such as cytochrome C. Others such as $\mathrm{Zn}, \mathrm{Mn}$ and $\mathrm{Cu}$ are also basically required by large number of enzymes for their catalytic activities [6]. Prolonged deficiencies of some mineral elements can manifest in several symptoms of malnutrition. Hence, supplementing SNS sample in diets to avert health issues, which is the primary aim of this product development would be achieved. Furthermore, the rare presence of hazardous elements $(\mathrm{Pb}, \mathrm{Cd}, \mathrm{Cr}$, and $\mathrm{Sn}$ ) indicated that the vegetation for cropping the cereals and legumes used in the study had not suffered serious effects of climate-change.

\subsection{Vitamin content}

The vitamin content of SNS (Table 5) revealed highest equivalent concentration of about $7.0 \mathrm{mg} / 100 \mathrm{~g}$ of vitamins $\mathrm{B}_{6}$ and $C$ while the least was vitamin $\mathrm{E}(0.05 \mathrm{mg} / 100 \mathrm{~g})$. Among the vitamin B vitamers, the least was $\mathrm{B}_{3}$ (niacin) $(0.39$ $\mathrm{mg} / 100 \mathrm{~g}$ ). The result had shown that while maize is deficient is known to be deficient in vitamins $\mathrm{B}_{12}$ and C [34], SNS formulation has aided their supplementation by 21- and 68-fold respectively. The positive antioxidant property of vitamin $C$ would synergize with the available Vitamin A. Relative to maize, particularly the yellow variety, SNS sample was 20 times in relative abundance of vitamin A, but had only $3 \%$ vitamin $\mathrm{E}$ and $10 \%$ vitamin $\mathrm{B}_{3}$ (niacin) contents.

Furthermore, the result had shown that the high temperature/short/time treatment of toasting in the processing of SNS had no deleterious effect on specific vitamins such as A, and C. The negative effect of soaking through leaching of watersoluble vitamins was also considered insignificant, though vitamin $\mathrm{C}$ and $\mathrm{E}$ activities could readily be lost through oxidation reactions.

It implied that vitamin A was probably present more in the precursor form of carotenoids, called provitamin A carotenoids (pVAC). Unlike the white variety without pVAC, common yellow maize is known to contain up to $2.0 \mu \mathrm{g} / \mathrm{g}$ Pixley et al. [35], and can be biofortified up to $66.0 \mu \mathrm{g} / \mathrm{g}$ Taelon et al. [36] - a commercial practice which began in Zambia, Ghana, and Nigeria in 2013. Hence, the yellow maize purchased for this study was likely the biofortified cultivar, and to have significantly contributed to the $38.0 \mu \mathrm{g} / \mathrm{g}$ pVAC obtained for the SNS sample.

Hence, SNS sample could be utilized as a supplementary source of vitamin A, which plays a central role in vision, immune system, gene and development of embryo. It could also boost several biochemical reactions as it contains a good amount of vitamin B-complex, particularly the $\mathrm{B}_{6}$. In addition, the residual concentration of vitamin $\mathrm{C}$ in SNS had the potential to inhibit inflammation and, oxidative damage that play a major role in the initiation and progression of several acute and chronic diseases; an indication that the SNS sample possessed some secondary antioxidant property capable of reducing oxidative stress.

\subsection{Fatty acid profile}

Fatty acid composition of plant seeds is known to be influenced by factors of genotype, climatic conditions, and growth location [37], and that as oleic acid concentration increases, linoleic acid concentration decreases with seed maturity [17].

Groundnut as an oilseed component of SNS significantly contributed to the crude lipid content of $18.6 \%$ (Table 2). The result of fatty acid profile (Table 6) showed that the SNS sample had the highest concentration of fatty acid as oleic acid (59\%). The other prevalent fatty acids were linolenic acid, (16\%), stearic acid (12\%), and arachidonic acid (8\%). Linoleic acid was the least (4\%) among the polyunsaturated fatty acids while stearic acid was the major saturated fatty acid available in significant quantity. 
Even on comparison with those of groundnut kernel and soybean obtained from literature (Table 6), the fatty composition of SNS sample differed significantly in concentration $(\mathrm{p}<0.05)$ irrespective of the fact that these two sources were ingredients used in formulating SNS. The results, therefore, indicated that SNS sample would exhibit its own characteristic functional properties as variants of any of its ingredients.

The significance of the fatty acid composition of SNS in nutrition was clearly demonstrated by the available omega- 6 (linoleic, arachidonic) and omega-3 (oleic) fatty acids. On consumption, the body would metabolize the former to lower concentrations of other forms of omega-3 fatty acids such as eicosapentaenoic (EPA), docosapentaenoic (DPA), and docosahexaenoic acids (DHA) [4]. Arachidonic acid (eicosatetraenoic acid) was present at 8\% level in SNS, resulting most likely as extract from the groundnut item used in the formulation. It is a central precursor of several known eicosanoids (prostaglandins, lipoxins, and leukotrienes) of biochemical and medical significance.

The relatively low abundance of saturated fatty acid (SFA, 12\%) makes the SNS flour a recommendable item in several food products intended for human consumption, because of its potential favorable disposition on the cardiovascular system. High level of SFA, mainly of $\mathrm{C}_{12}$ to $\mathrm{C}_{16}$, correspondingly increases the level of blood cholesterol [38]. WHO and FAO had recommended PUFA/SFA and $\omega 6 / \omega 3$ ratios for 'balanced diet' to be greater than 0.4 and less than 4.0 respectively [17]. This study recorded 3.2 and 0.7 respectively, which none of the ingredients of SNS would had satisfied the requirements (Table 6). Furthermore, the shelf-life of oily food products is dependent on its oxidative stability, dictated by degree of unsaturation and iodine value. The calculated mono/poly unsaturation ratio was (2.2), denoting the low level of polyunsaturated fatty acids present which would have readily disposed SNS to oxidation, and rancidity at short storage period. Coupled with the recorded 97\% dry matter, SNS composite flour therefore, would exhibit long shelf-stability.

\subsection{Amino acid composition}

The percentage (\%) concentrations of amino acids in the SNS protein were compared with those of soya bean and groundnut as shown in Table 7. Of the 20 known standard amino acids in protein, 18 were found in the SNS composite flour. Leucine activates the release of insulin, and is claimed to be the most important amino acid for building muscular mass, while tryptophan serves as a precursor of serotonin neurotransmitter [39]. From this study, leucine and tryptophan were the prevalent amino acids in the SNS sample and contributing 57\% of the essential amino acids present, while methionine was the limiting amino acid. The second order of limiting amino acids observed was histidine and valine. These amino acids had significantly different concentrations compared with their constituent groundnut and soya bean samples $(\mathrm{p}<0.05)$.

Furthermore, cereals such as maize and guinea corn (sorghum) used in SNS formulation are commonly deficient in leucine, lysine, tryptophan, and/or threonine $[40,41,42]$. Some of the essential amino acids particularly, lysine and threonine which are in relatively higher abundance in the leguminous ingredients (soya bean and groundnut) of SNS (Table 7, p<0.05) would be able to complement adequately for such deficiency on consumption of SNS-based diets. To further meet essential amino acid requirements of such diets, isoleucine concentrations of SNS, soya bean and groundnut were observed to be similar $(\mathrm{p}<0.05)$, and significantly higher than the FAO/WHO recommended value of $2.8 \mathrm{~g}$ isoleucine $/ 100 \mathrm{~g}$ protein (Table 7 ).

The advantage of dietary intake of SNS products was further justified by the relatively higher abundance of some 'semiessential' amino acids such as glutamine, glycine, cysteine, and proline, compared with those of soya bean or groundnut alone $(\mathrm{p}<0.05)$. Even arginine with the least concentration in the SNS sample could be boosted via the catabolism of proline or glutamine which already exists in highest concentration. Excess arginine counteracts excess and toxic ammonia produced via the urea cycle. Thus, arginine is of health benefit to premature infants and individuals with severe catabolic stress; examples include HIV/AIDS-diagnosed patients and subjects with symptoms of protein-energy malnutrition (PEM), who the goal of this study targets.

Furthermore, Table 7 showed that children of pre-school age in the range of 2 to 5 years would benefit significantly from consuming SNS-based products. This was evident in the observed range of $47-213 \%$ which the SNS composite flour met the FAO/WHO [40] minimum requirements of 40\% essential amino acids. The contribution was principally from six essential amino acids namely, $47 \%$ valine, $61 \%$ lysine, $76 \%$ histidine, $82 \%$ threonine, $118 \%$ isoleucine, and $213 \%$ leucine. Phenylalanine was also relatively higher in concentration in SNS than soya bean or groundnut, as well as being the third most abundant essential amino acid. 
The FAO/WHO [43] also specified a minimum 0.6 ratio of essential to non-essential amino acids, while the calculated SNS value was (0.87). It implied that SNS could readily provide improved amino acid scores for quality protein synthesis, when supplemented in diets.

\section{Conclusion}

The formulated composite flour, SNS, had dry matter content of $97 \%$, and rich in crude protein and oil contents. Gross energy content was $4.64 \mathrm{kcal} / \mathrm{g}$ SNS. The processing steps of soaking and dehulling for some ingredients leached and significantly decreased the contents of some water-soluble vitamins, phytochemical and anti-nutritional substances. The attendant loss in the preservative effects of some phytochemicals and shelf-life of SNS, was to be compensated by the high quality fatty acid profile. Nutritionally, SNS met the minimum PUFA/SFA and $\omega 6 / \omega 3$ ratios expected of FAO/WHO, contained appreciable amounts of calcium, phosphorus, magnesium (8 - $17 \mathrm{mg} / \mathrm{g})$, pro-vitamin A, vitamins $\mathrm{B}_{6}, \mathrm{~B}_{12}$, and $\mathrm{C}$. Furthermore, significantly higher contents of four essential amino acids (leucine, tryptophan, phenylalanine, and isoleucine) than the recommended standards $(\mathrm{p}<0.05)$ were observed. Hence, regular dietary intake of Sumain Nutritional Supplement (SNS) with vitamin E-rich foods was advocated for children, and adults experiencing severe catabolic stress of immune-deficiency and protein-energy malnutrition.

\section{Compliance with ethical standards}

\section{Acknowledgments}

The authors deeply appreciate the Tertiary Trust Fund (TETFUND), Nigeria for sponsorship. The technical assistance of Omada, AA, Tijani M, John, SW and personnel of various Laboratories engaged for the research are also acknowledged.

\section{Disclosure of conflict of interest}

The authors hereby declare no conflict of interest for the purpose of the present research.

\section{Author's contributions}

Akpala envisioned the study and participated in the conduct of the experiments with the co-authors (Amlabu, Amodu, and Arogba). In addition, Arogba designed the methodologies, supervised the experimentation, analysed the data, and scripted the article.

\section{References}

[1] Awadalkareem AM, Mustafa AI and El Tinay AH. (2008). Protein, Mineral Content and Amino Acid Profile of Sorghum Flour as Influenced by Soybean Protein Concentrate Supplementation. Pakistan Journal of Nutrition, $7(3), 475-479$.

[2] Alcantara BK, Rizzi V, Salete AG and Azevedo RA. (2017). Soluble amino acid profile, mineral nutrient and carbohydrate content of maize kernels harvested from plants submitted to ascorbic acid seed priming. Annals of the Brazilian Academy of Sciences, 89(1), 695-704

[3] Kokten K, Kocak A, Kaplan M, Akcura M, Bakoglu A and Bagci E. (2011). Tannin, Protein Contents and Fatty composition of the Seeds of some Trifolium L. species from Turkey. Asian Journal of Animal and Veterinary Advances, 6(1), 88 - 95.

[4] Daley CA, Abbott A, Doyle P, Nader, GA and Larson S. (2010). A review of fatty acid profile and antioxidant content in grass-fed and grain-fed beef. Nutrition Journal, 9(10), 1 - 12.

[5] Kan A. (2015). Characterization of the Fatty Acid and Mineral Compositions of Selected Cereal Cultivars from Turkey. Records of Natural Products, 9(1), $124-134$.

[6] Soetan KO, Olaiya CO and Oyewole OE. (2010).The importance of mineral elements for humans, domestic animals and plants: A review. African Journal of Food Science, 4(5), $200-222$. 
[7] Mamede AC, Tavares SD, Abrantes AM, Trindade J, Maia JM and Botelho MF. (2011).The Role of Vitamins in Cancer: A Review. Nutrition and Cancer, 63(4), 479 - 494.

[8] IITA. (1990). Removal of Anti-nutritional Husk from Flour Preparation. Bulletin of International Institute of Tropical Agriculture (IITA), Ibadan, Nigeria.

[9] Pearson D. (1976). The Chemical Analysis of Foods. (7th ed.). RK Churchill Livingstone, Edinburgh, UK.

[10] Nana FW, Hilou A, Millogo JF and Nacoulma OG. (2012). Phytochemical composition, Antioxidant and Xanthine oxidase inhibitory activities of Amaranthus cruentus L. and Amaranthus hybridus L. extracts. Pharmaceuticals, $5(6), 613-628$.

[11] Danso J, Alemawor F, Boateng R, Barimah J and Kumah DB. (2019). Effect of drying and anti-nutrient composition of Bombax buonopozense sepals. African Journal of Food Science, 13(1), 21 - 29.

[12] Obadoni BO and Ochuko PO. (2001). Phytochemical studiesnand comparative efficacy of crude extract of some homeostatic plants in Edo and Delta States of Nigeria. Global Journal of Pure and Applied Sciences, 86, $203-208$.

[13] AOAC. (1990). Association of Official Analytical Chemists. Official Methods of Analysis of AOAC International, 15th edn., Washington, DC.

[14] AOAC. (2005). Association of Official Analytical Chemists. Official Methods of Analysis of the AOAC International, 18th edn., Gaithersburg, MD.

[15] Ogunsina BS, Bhamagar AS, Indira TC and Radha C. (2012). The proximate composition of African Mango kernels (Irvingia gabonensis) and characteristics of its oil. Ife Journal of Science, 14(1), 177 - 183.

[16] AACC. (2000). American Association of Cereal Chamists. Approved Methods. 10th ed. St Paul. MN: American Association of Cereal Chemists International.

[17] Nile SH and Park SW. (2013). Fatty acid composition and antioxidant activity of groundnut (Arachis hypogaea L.) products. Food Science and Technology Research, 19(6), 957 - 962.

[18] Ivanov DS, Levic JD and Sredanovic SA. (2010). Fatty acid composition of various soybean products. Food and Feed Research, 2, $65-70$.

[19] Anon. (2019). What is Sacha inchi (Plukenetia volubilis)? The Green Labs LLC, New Jersey, USA.

[20] Uguru MI. (2011). Crop production tools, techniques and practice. Revised Edn. Fulladu Publishing Co., Nsukka, Nigeria.

[21] Aletor 0. (2010). Nutritive and physico-chemical characteristics of some plant and animal-based concentrates. International Journal of Chemical Sciences, 2(2), 155 - 165.

[22] Kohler R, Kariuki L, Lambert C and Bielsalski HK. (2019). Protein, amino acid and mineral composition of some edible insects from Thailand. Journal of Asia-Pacific entomology, 22(1), $372-378$

[23] Pomeranz Y and Clifto D. (1981). Food Analysis, Theory, and Practice. In: Melon EE (Ed.). Chemical Food Analysis Practical Manual - Chemistry. Avi Publishing Co. Westport, CT.

[24] Andualem B and Gessesse A. (2014). Proximate composition, mineral content and anti-nutritional factors of Brebra (Millettia feruginea) seed flour as well as physical characterization of its oil. Springerplus, 3, $298-331$.

[25] Ekop AS. (2007). Determination of chemical composition of Gnetum africanum (Afang) seeds. Pakistan Journal of Food and Nutrition, 6, 37 - 40.

[26] Yadav RNS and Agarwala M. (2011). Phytochemical analysis of some medicinal plants. Journal of Phytology, 3(12), $10-14$.

[27] Arogba SS and Omede A. (2012). Comparative Antioxidant Activity of Processed Mango (Mangifera indica) and Bush Mango (Irvingia gabonensis) Kernels. Nigeria Food Journal, 30(2), 17 - 21.

[28] Bozin B, Mimica-Dukic N, Samojlic I, Goran A and Igic R. (2008). Phenolics as antioxidants in garlic (Allium sativum L.). Food Chemistry, 111, 925 - 929. 
[29] Horner HT, Cervantes-Martinez T, Healy R, Reddy MB, Deardorff BL, Baailey TB, Al-Wahsh I, Massey LK and Palmer RG. (2005). Oxalate and phytate concentrations in seeds of soybean cultivars (Glycine max (L.) Merr. Journal of Agricultural and Food Chemistry, 53, 7870 - 7877.

[30] Zhou R, Cai W and Xu B. (2017). Phytochemical profiles of black and yellow soybeans as affected by roasting. International Journal of Food Properties, 20(12), 3179 - 3190.

[31] Gloria MBA. (2003). Sweeteners. In: Caballero B. (Ed.). Encyclopaedia of Food Sciences (2nd edn.). ISBN 978-012-227055-0. Academic Press, 5695 - 5702.

[32] Girish C and Pradhan SC. (2017). Herbal Drugs on the Liver. In: Muriel P. (Ed.). Liver pathophysiology: Therapies and Antioxidants. ISBN 978-0-12-804274-8. Academic Press, 605 - 620.

[33] Ramos-Tovar ER and Muriel P. (2019). Phytotherapy for the Liver. In: Watson RR and Preedy VR. (Ed.). Dietary Interventions in Liver Disease: Foods, Nutrients, and Dietary Supplements. ISBN 978-0-12-814466-4. Academic Press, 428.

[34] Tanumihardjo SA and Suri DJ. (2016). Effects of different processing methods on the micronutrient and phytochemical contents of maize: From A to Z. Comprehensive Reviews in Food Science and Food Safety, 15(5), $912-926$.

[35] Pixley K, Palacios-Rojas N, Babu R, Mutale R, Surles R and Simpungwe E. (2013). Biofortification of maize with provitamin A carotenoids. In Tanumihardjo SA. (Ed/), Carotenoids and human health. Springer Science, New York, $271-292$.

[36] Taleon V, Mugode L, Cabrera-Soto L and Palacios-Rojas N. (2017). Carotenoid retention in biofortified maize using different post-harvest storage and packaging methods. Food Chemistry, 232, 60 - 66.

[37] Anderson PC and Gorbet DW. (2002). Influence of year and planting date on fatty acid chemistry of high oleic acid and normal peanut genotype. Journal of Agricultural and Food Chemistry, 50, 1298-1305.

[38] Cater NB and Denke MA. (2001). Behenic acid is a cholesterol-raising saturated fatty acid in human. American Journal of Clinical Nutrition, 73, $41-44$.

[39] Aledo JC. (2007). Glutamine breakdown in rapidly dividing cells: Waste or Investment? Bioassays, 26(7), 479 494.

[40] Van-Huis A, van-Itterbeeck J, Klunder H, Mertens E, Halloran, A, Muir G and Vantomme P. (2013). Edible Insects: Future Prospects for Food and Feed Security. Food and Agriculture of the United Nations, Rome, xvi, 187.

[41] Mokrane H, Amoura H, Belhaneche-Bensemra N, Courtin CM, Delcour JA and Nadjemi B. (2010). Assessment of Algerian sorghum protein quality [Sorghum bicolor (L.) Moench] using amino acid analysis and in vitro pepsin digestibility. Food Chemistry, 121, $719-723$.

[42] Salunkhe DK, Kadam SS and Chavan JK. (1977). Nutritional quality of proteins in grain sorghum. Qualitas plantarum, 27(2), 187 - 205.

[43] FAO/WHO. (1973). Energy and Protein requirements: Report of a joint FAO/WHO Ad Hoc Expert Committee, Rome, 22 March - 2 April 1971, Geneva, 118 s.

\section{How to cite this article}

Arogba SS, Akpala SN, Amlabu E and Amodu L. (2020). Sumain nutritional supplement: Formulation, physico-chemical and nutritional assessment of its flour. GSC Biological and Pharmaceutical Sciences, 10(3), 137-149. 